\title{
THE CHALLENGES OF APPLICATION OF THE HYBRID LEARNING MODEL IN GEOGRAPHY LEARNING DURING THE COVID-19 PANDEMIC
}

\author{
Singgih Prihadi ${ }^{1, *}$, Sajidan $^{1}$, Siswandari $^{1}$, Sugiyanto $^{1}$ \\ ${ }^{1}$ Education Science, Universitas Sebelas Maret \\ *Email: singgihprihadi82@student.uns.ac.id
}

\begin{abstract}
Since the beginning of 2020, the COVID-19 pandemic has occurred, Indonesia has implemented distance learning. Higher education also conducts learning with a hybrid learning model. The hybrid learning model applied is of the full type, meaning that it is carried out fully online. Geography learning that is carried out online is still trying to equip students to increase spatial citizenship skills. This study seeks to find out how the challenges of implementing the hybrid learning model in geography learning in the geography education study program are FKIP UNS. The method used in this research is descriptive qualitative. The research subjects were second semester students, geography education study program FKIP UNS. The data collection techniques used were interviews, observations and FGD. The result of this research is that geography learning, which is carried out using a hybrid learning model, can effectively achieve mastery of students' spatial citizenship skills. The hybrid learning model that is applied must be combined with other platforms such as Zoom Meeting, Moodle, WhatsApp and Open Course Ware.
\end{abstract}

Keywords: Hybrid Learning; Geography Learning; Spatial Citizenship

\section{A. INTRODUCTION}

Since the spread of the COVID-19 virus in early 2020 until now, it has caused many problems in the field of education. For almost 2 years, education in Indonesia has implemented distance learning from early childhood education to higher education. This policy is carried out as an effort to reduce the number of victims infected with the COVID-19 virus. According to UNESCO (2020) it was explained that the COVID-19 pandemic had affected the education system in the world, including in Indonesia, so distance learning was implemented. The COVID-19 pandemic is a very difficult challenge for lecturers and students in higher education. Lecturers cannot stop teaching during a pandemic. Lecturers are required to be creative to carry out online learning. Students must also prepare equipment from a computer or laptop connected to the internet so that the online learning process can be carried out. Higher education, which in general has been facilitated by adequate internet technology, is still experiencing problems in the learning process. Crawford \& Jenkins (2017) say that to improve the accessibility of technology, it is necessary to use a flexible online learning 
platform and have priority to achieve learning effectiveness.

In the context of higher education, it is necessary to develop an online learning speed that is consistent with the expectations of society. Hybrid or mixed learning is designed to navigate the complex and implicated components of the changing pedagogical paradigms in all of these digital transitions. According to Hediansah \& Surjono (2020) it is explained that teacher learning management is an important part to achieve the effectiveness of learning processes and outcomes. This is based on the development of the Industrial Revolution 4.0 technology which is part of the sustainability of $21^{\text {st }}$ century educational innovation. Research conducted by Hediansah \& Surjono shows that there is a positive response from teachers regarding learning management using a hybrid learning model. The hybrid learning model has an interactive impact and helps facilitate independent learning.

Students study from their respective homes scattered throughout Indonesia. Differences in the geographical conditions of the regions in Indonesia have a major influence on the process of distance learning. There are students whose areas are still difficult to receive the internet network. This causes the online learning process does not run smoothly. According to Smaldino, E, S., Lowther, D, L., Mims, C \& Russel, J (2015) it is explained that technology is an inseparable part of $21^{\text {st }}$ century education. $21^{\text {st }}$ century education requires an innovation in the use of media and technology in a directed manner so that it can provide an important role for every individual who carries out the learning process. Technological developments will have a significant impact on the process of information transfer in the field of education. Education must be able to provide meaning for students and lecturers through optimizing internet technology assistance. Ideally, learning is carried out with a combination of face-toface and virtual, so that the process of delivering knowledge and internalizing moral values can be carried out properly. But this cannot be done because of restrictions on activities that many people participate in during the COVID-19 pandemic, one of which is face-to-face learning in class. In higher education, finally, full hybrid learning is carried out, namely learning is carried out using zoom meetings without any face-to-face meetings. Fung Choy \& Quek (2016) conducted a study that with advances in technology, many students spend time studying online. Fung Choy \& Quek examined the relationship between 
elements perceived by students in online learning, namely social conditions, cognitive, satisfaction and performance related to academic and sustainable achievement.

In online learning, only cognitive elements have a direct relationship with academic performance and achievement. With regard to online learning, Czerkawski (2016) explains that with the advent of web-based software, it provides convenience in online learning and provides a very valuable opportunity for formal and informal learning. Czerkawski examined students in the use of online learning networks in formal and informal classes to find out how the interaction of the two, whether they affect each other. Chaeruman (2010) said that in the world of education, especially teachers who act as the first person directly involved in the learning process, it is necessary to have a learning strategy that uses various appropriate learning media technologies to achieve effective and efficient learning goals.

The process of implementing learning in the Geography Education Study Program which was carried out online went smoothly. The application of hybrid learning with the full online method can be followed by all students and lecturers. In the learning process, there were only obstacles at the beginning, namely the problem of the zoom meeting platform which was not owned by the lecturers. In the end, it was facilitated by the faculty by providing three zoom meeting platforms for each study program for free. The second problem is that some of the lecturers have not mastered the use of zoom meetings, which is then held training on the use of virtual learning platforms at the study program level. The third problem is that some students who live outside Java experience internet network problems. But in general the implementation of hybrid learning went smoothly. Anders (2015) once conducted a study whose results were that the hybrid learning model could facilitate student diversity in the context of online learning. The hybrid learning model focuses on the participation patterns and experiences of students who are doing online learning.

Ali Alammary, Judy Sheard (2014) mentions that hybrid learning is increasingly popular for online learning. In the beginning, this mixed learning poses a big challenge for higher education institutions to implement it. This is very relevant to the current pandemic conditions, which occurred in early 2020. At the beginning of 2020, with the implementation of distance learning policies for basic education to higher education, it is required that 
learning must be fully online. Many lecturers at universities are still confused about using the hybrid learning model. Over time, many trainings on the use of virtual learning platforms began. The hybrid learning model has finally become a solution for the application of online learning. The case in the Geography Education Study Program in relation to the technicality of the hybrid learning process can be concluded to be running quite well, but related to the level of understanding of spatial concepts given online, student abilities are still low.

\section{B. MATERIALS AND METHODS}

The method used in this research is descriptive qualitative. The data collection techniques used were observation, interviews and Focus Group Discussion (Miles, 1992). Observations were made on online learning using the Zoom Meeting platform and Moodle SPADA UNS. This observation was carried out on students of the 2020 Geography Education Study Program which consisted of three classes. The researcher is a passive observer and is unknown to the students. Observations were made on the geography learning process for 8 meetings, in February-April 2021.

Interviews were conducted on lecturers and study program administrators. The interview process is carried out at the same time as the observations, with flexible timing to adjust the time of the lecturers and study program administrators. Focus group discussions are conducted between researchers, supporting lecturers, study program administrators, and experts. Focus group discussion activities were carried out twice in the middle of March to April 2021. There are two types of data in this study, namely quantitative data in the form of student assignment scores and qualitative data in the form of data from observations, interviews and focus group discussions.

The data analysis technique used is interactive data analysis consisting of data collection, data condensation, data presentation, and drawing conclusions. This interactive data analysis activity is carried out continuously until it is completed. At the data condensation stage, it is carried out continuously during the research process with the aim of identifying, sharpening, directing and discarding data that are not appropriate or not needed in the study. Data condensation was carried out to make it easier for researchers to carry out the next data collection process. At the data presentation stage, it can be presented in the form of tables, charts, graphs, brief descriptions, and diagrams. This stage of 
data presentation can make it easier for researchers to understand everything that happens to the object of research. In addition, it will make it easier for researchers to plan the next work program. At the conclusion or verification stage, this is an initial conclusion that is still temporary. Strive to draw conclusions supported by strong, valid and consistent evidence when researchers return to the field.

\section{RESULTS AND DISCUSSION}

Spatial citizenship skills are needed by students in the Geography Education study program. This ability has not yet been developed in a structured manner by the study program. From the results of the research conducted, it is known that the spatial citizenship skills given to students through hybrid learning are quite effective. Hybrid learning is carried out in geography learning using the zoom meeting platform, Moodle SPADA, WhatsApp group, and Open Course Ware. The hybrid learning model applied in the Geography Education Study Program that uses Moodle has a function to facilitate interaction between lecturers and students or students and students in the online learning process. This interaction is supported by various conveniences in entering material, sending assignments, discussing together, and conducting assessments.

In Moodle itself, other platforms can also be included in it for virtual meetings, which use the Big Blue Button application. It's just that most students feel that virtual meetings using Big Blue Button are too difficult to access. In the end, virtual meetings use the zoom meeting platform which is easier and faster to access, it's just that you have to use paid zoom meetings. To facilitate the online learning process, the use of zoom meetings has been facilitated by the study program. The hybrid learning model using Moodle also serves to increase the effectiveness of collaboration between lecturers and students or students with students. Easy access anytime and anywhere, making Moodle an effective hybrid learning model platform. However, this is also supported by other platforms that are used interchangeably or simultaneously. The use of Moodle in the hybrid learning model in the Geography Education Study Program can also encourage students to actively do independent learning. The opportunity to access various learning resources on Moodle is very well facilitated. Through this Moodle, students will also quickly get feedback from lecturers during activities in discussion forums. 
Although the implementation of hybrid learning was relatively smooth, there were several challenges in the process. However, this still has to be developed because hybrid learning is the only effective model during a pandemic that requires distance learning. Regarding the ability of spatial citizenship through hybrid learning, it can be explained as follows.

1. Map reading, orientation and navigation

From the research conducted, in the hybrid learning process, lecturers use the Google Earth application so that students are introduced to how to read maps, determine orientation and navigation. However, there are still many students who do not fully understand the map. As many as $19.51 \%$ of students have difficulty reading maps, determining orientation and navigating through hybrid learning. This means that the hybrid learning model in geography learning is very effective because $80.49 \%$ of students are able to master map reading, orientation and navigation.

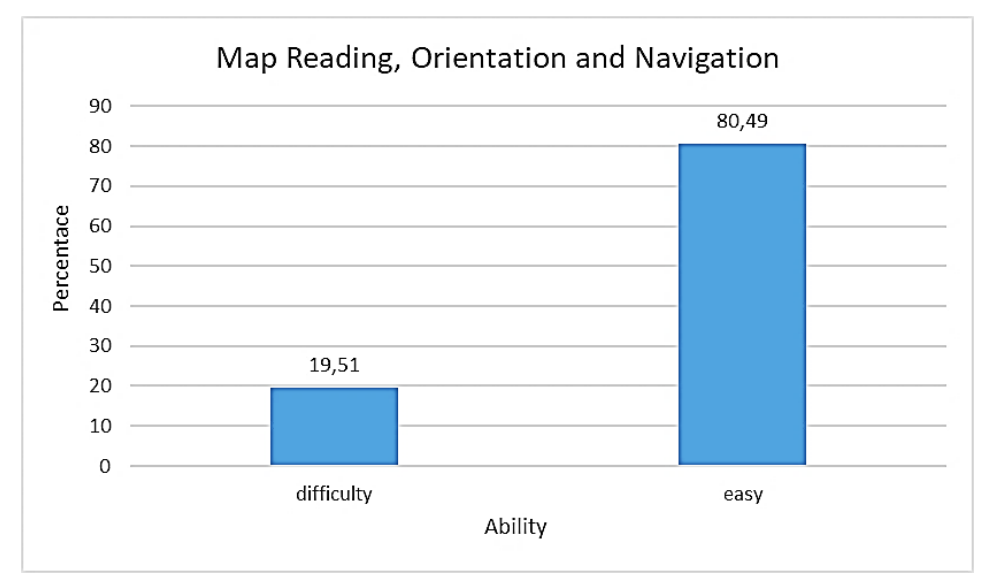

Figure 1. Map Reading, Orientation and Navigation

2. Analyze specific functions to answer simple questions that fulfill the task analysis step and develop hypotheses from space representations

From the research conducted, it is known that as many as $54.88 \%$ of students find it difficult to answer analytical questions, develop hypotheses from spatial representations. From the results of interviews with teaching lecturers, this is because there are still many students whose concentration is broken because online learning cannot be conditioned. Student residences in various regions with different facilities, different levels of network connections, and low level of awareness of students participating in learning, greatly affect students' ability to think critically and analytically. 


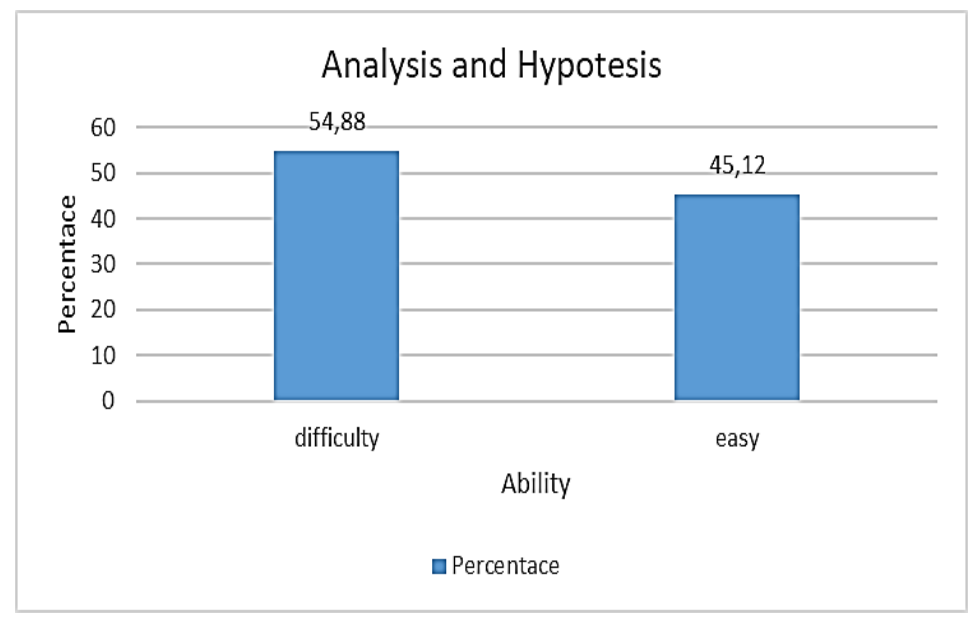

Figure 2. Analysis and Hypotheses

3. Selecting data and presenting it in the form of visualization

From the research conducted, it is known that as many as $37.8 \%$ of students have difficulty in selecting data and presenting it in the form of visualization. This happens because students have difficulty discussing face to face directly with other students in completing learning tasks.
However, in future developments, hybrid learning will not be constrained to facilitate discussions and work on completing assignments in groups, for example with the help of Microsoft 365 . However, currently there are still many students who do not have a Microsoft 365 account.

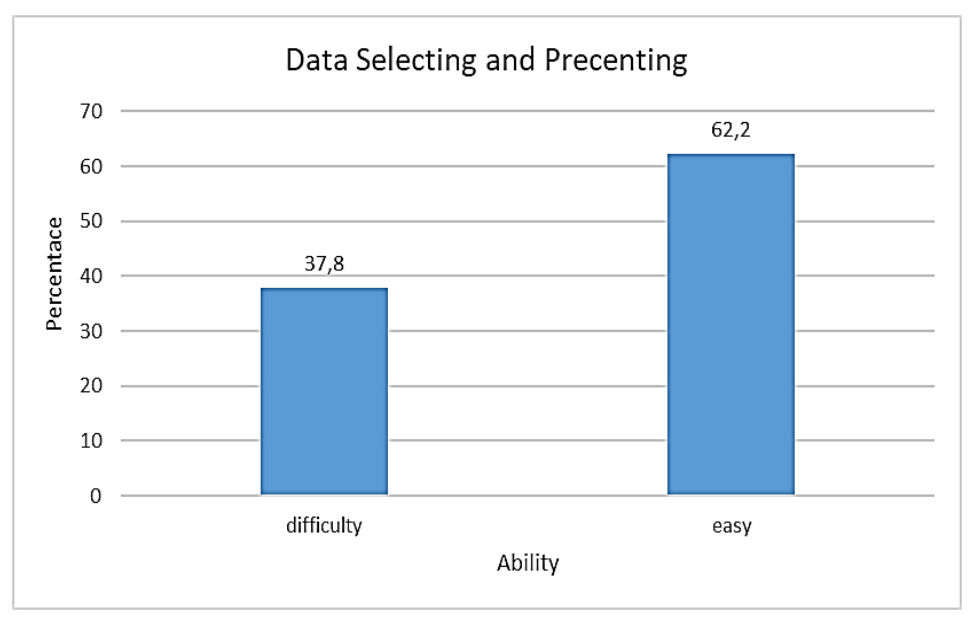

Figure 3. Data Selecting and Precenting 


\section{Producing own data and ideas}

From the research conducted, it is known that as many as $48.78 \%$ of students find it difficult to produce their own data and ideas. This means that almost half of the total students are not yet skilled in developing creative ideas. It is necessary to combine hybrid learning with several platforms, for example using zoom meetings with additional e-module or e-book facilities that can be accessed by students through the SPADA portal.

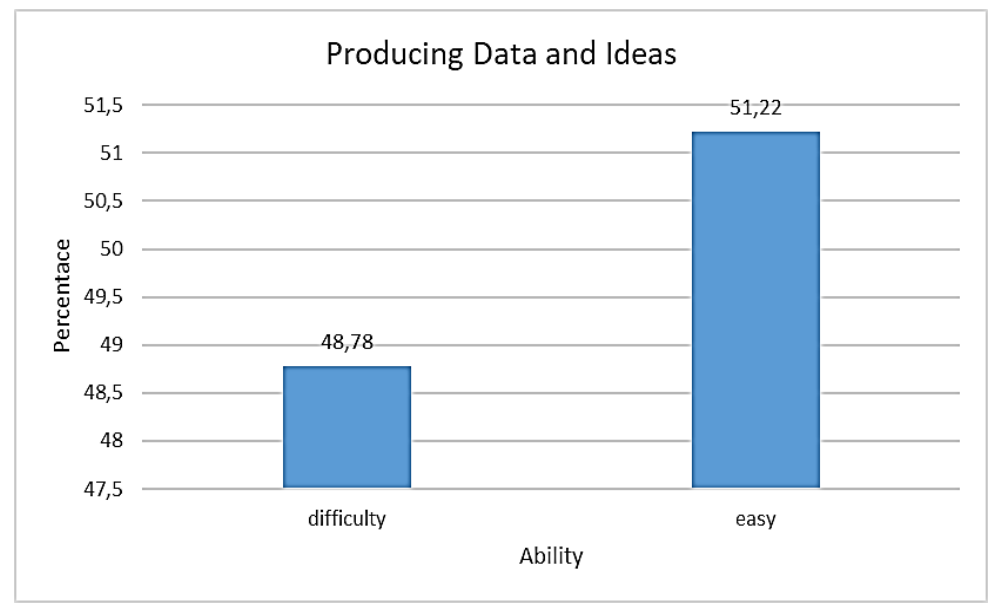

Figure 4. Producing Data and Ideas

\section{Using social networks}

From the research conducted, it is known that as many as $13.41 \%$ students still have difficulty in using social networks. It can be concluded that this is not a problem. Students who have difficulty in publishing their work on social networks are caused by the fact that these students are not very motivated to use social media.

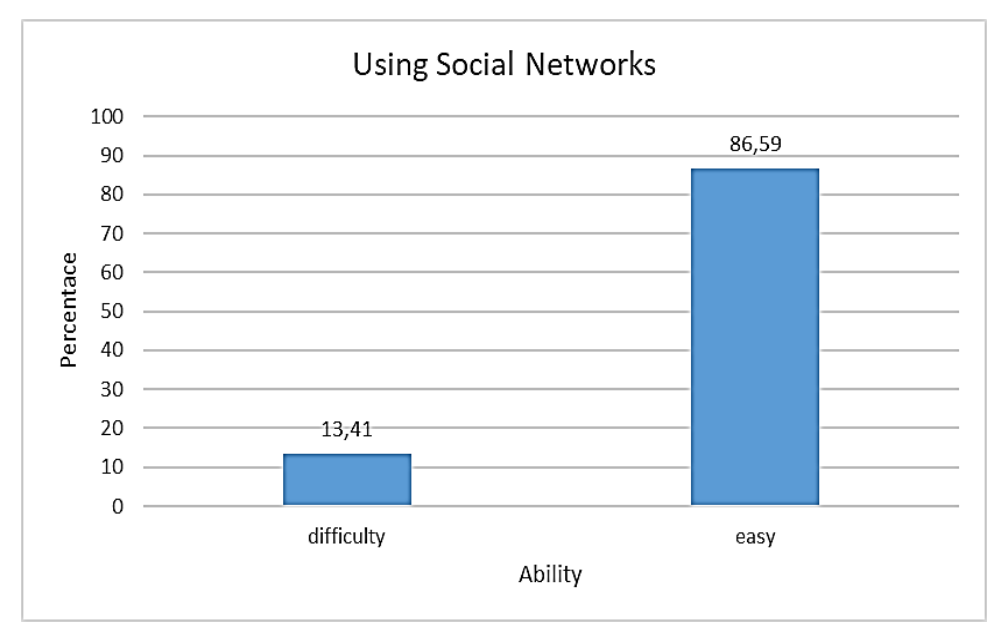

Figure 5. Using Social Networks 
The implementation of the learning process with the hybrid learning model has an impact on students and lecturers. The application of the hybrid learning model really helps lecturers and students reduce stress and learning difficulties during a pandemic that requires distance learning. Through the application of the hybrid learning model in the geography education study program, it makes learning more innovative and still able to provide students with spatial citizenship skills. Innovation in the application of the hybrid learning model needs to be carried out by being equipped with platforms that support the smooth running of virtual learning.

\section{CONCLUSIONS}

The hybrid learning model applied in the Geography Education Study Program is a learning model that uses fully online learning. The full implementation of the hybrid learning model uses internet facilities continuously during face-to-face processes or interactions between lecturers and students. This model uses synchronous and asynchronous techniques. For synchronous techniques, it requires lecturers and students to standby on the internet at the agreed time. For asynchronous techniques, lecturers and students do not meet virtually, but lecturers and students access the elearning portal at any time. Boelens et al (2017) in his writings, said that content is the most important part in the development of a hybrid learning model because it becomes a reference and impact of the learning process. Content must be well structured and attractive. Regarding the effectiveness of hybrid learning, Kudryashova et al., (2016) explained that the hybrid learning model applied in the learning process can help students gain knowledge and skills effectively. The presentation of concepts in the hybrid learning model must be comprehensive and the dissertation with relevant examples will be easy for students to understand.

The hybrid learning model facilitates the process of learning geography in the $21^{\text {st }}$ century effectively. Chalkiadaki (2018) says that in the $21^{\text {st }}$ century a dynamic person is needed in responding to all social changes that occur. This is evidenced by the achievement of the objectives of learning geography in the semester evaluation. Students can play an active role in participating in online learning. But in practice, there are challenges faced by lecturers, namely there are still many students who do not activate the camera during online learning through zoom 
meetings, so they cannot be monitored by lecturers. Seeing the condition of these students, many lecturers in the Geography Education Study Program took the initiative to require students to activate the camera during online learning through zoom meetings. The achievement of geography learning remains a concern as long as learning is carried out online. Indicators of students' spatial citizenship abilities can be achieved through a hybrid learning model that is combined between Zoom Meeting, Moodle, WhatsApp, and Open Course Ware.

\section{E. REFERENCES}

Ali Alammary, Judy Sheard, A. C. (2014). Blended learning in higher education: Three different design approaches Ali. Australasian Journal of Educational Technology, 30(12).

Anders, A. (2015). Theories and Applications of Massive Online Open Courses (MOOCs): The Case for Hybrid Design. International Review of Research in Open and Distance Learning, 16(6), 39-61. https://doi.org/10.19173/irrodl.v1 $6 i 6.2185$

Boelens, R., De Wever, B., \& Voet, M. (2017). Four key challenges to the design of blended learning: A systematic literature review. Educational Research Review, 22(June), 1-18. https://doi.org/10.1016/j.edurev.2 017.06.001
Chaeruman, U. (2010). E-Learning dalam Pendidikan Jarak Jauh. Kemendiknas.

Chalkiadaki, A. (2018). A systematic literature review of 21 st century skills and competencies in primary education. International Journal of Instruction, 11(3), 1-16. https://doi.org/10.12973/iji.2018. $1131 \mathrm{a}$

Crawford, R., \& Jenkins, L. (2017). Blended learning and team teaching: Adapting pedagogy in response to the changing digital tertiary environment. Australasian Journal of Educational Technology, 33(2), 51-72. https://doi.org/10.14742/ajet.2924

Czerkawski, B. C. (2016). Blending formal and informal learning networks for online learning. International Review of Research in Open and Distance Learning, 17(3), 138-156. https://doi.org/10.19173/irrodl.v1 $7 \mathrm{i} 3.2344$

Fung Choy, J. L., \& Quek, C. L. (2016). Modelling relationships between students' academic achievement and community of inquiry in an online learning environment for a blended course. Australasian Journal of Educational Technology, 32(4), 106-124. https://doi.org/10.14742/ajet.2500

Hediansah, D., \& Surjono, H. (2020). Hybrid Learning Development to Improve Teacher Learning Management. JKTP: Jurnal Kajian Teknologi Pendidikan, 3(1), 1-9. https://doi.org/10.17977/um038v 3i12019p001

Kudryashova, A. V, Gorbatova, T. N., \& Rozhkova, N. E. (2016). Developing a blended learning based model for teaching foreign. 
SHS Web of Conferences, 01128, 8-11.

https://doi.org/10.1051/shsconf/2 0162801128 Developing

Miles, M. B. dan A. M. H. (1992). Qualitative Data Analysis: A Sourcebook of New Method. Terjemahan Tjetjep Rohendi Rohidi. Analisis Data Kualitatif:
Buku Sumber tentang Metodemetode Baru. UI PRESS.

Smaldino, E, S., Lowther, D, L., Mims, C \& Russel, J, D. (2015). Instructional Technology and Media for Learning (11th). Pearson. 